\title{
Chemical and Electrochemical Coloration of Stainless Steel and Pitting Corrosion Resistance Studies
}

\author{
Elaine Kikuti, Rosangela Conrrado, Nerilso Bocchi*, Sonia R. Biaggio and Romeu C. Rocha-Filho \\ Departamento de Química, Universidade Federal de São Carlos, CP 676, 13560-970 São Carlos - SP, Brazil
}

\begin{abstract}
Filmes de óxidos coloridos foram crescidos sobre amostras de aço inoxidável AISI 304 por métodos químico e eletroquímicos usando diferentes tempos de coloração. Os métodos eletroquímicos utilizados foram pulsos alternados de potencial e varreduras triangulares de corrente. Os filmes coloridos foram caracterizados na região do visível por espectrofotometria no modo de refletância. A resistência à corrosão por pites das diferentes amostras coloridas foi avaliada a $25^{\circ} \mathrm{C}$ em $\mathrm{NaCl} 0,62$ mol L ${ }^{-1}$, usando curvas de polarização potenciodinâmicas, e em $\mathrm{HCl} 0,40 \mathrm{~mol} \mathrm{~L}^{-1}$, por espectroscopia de impedância eletroquímica. Independentemente do método de coloração usado, os filmes de óxido colorido apresentam um efeito protetor contra a corrosão por pites somente nas primeiras horas de exposição. Para tempos de exposição mais longos (8-10 h), as amostras de aço coloridas ou não coloridas apresentaram comportamentos semelhantes.
\end{abstract}

Colored oxide films were grown on AISI-304 stainless-steel samples by chemical and electrochemical methods using different coloring times. The electrochemical methods involved the use of alternating potential pulses and triangular current scans. The colored films were characterized in the visible region by reflectance spectrophotometry. Pitting corrosion resistance of the different colored steel samples was evaluated at $25^{\circ} \mathrm{C}$ in $0.62 \mathrm{~mol} \mathrm{~L}^{-1} \mathrm{NaCl}$, using potentiodynamic polarization curves, and in $0.4 \mathrm{~mol} \mathrm{~L}^{-1} \mathrm{HCl}$, by electrochemical impedance spectroscopy. Independently of the coloring method used, the colored oxide films showed a protective effect against pitting corrosion only in the first hours of exposition. For longer exposition times $(8-10 \mathrm{~h})$ the colored and noncolored steel samples presented similar behaviors.

Keywords: AISI-304 stainless steel, colored oxide films, steel coloring methods, pitting corrosion

\section{Introduction}

Stainless steel has important characteristics (such as versatility, durability, attractiveness and high mechanical and corrosion resistance), being widely used in several industries and architectural projects. When it is used for decorative purposes, its appearance requires special attention and thus its color becomes the major focus. Therefore, the standard color of stainless steels (light gray) does not always blend pleasingly with the environment in which they are used. However, when oxide films of different thicknesses are formed on stainless steel, different colors are perceived due to the interference of light reflected at the oxide film/air and steel/oxide film interfaces. ${ }^{1-11}$ Oxide films of different thicknesses can be grown on the stainlesssteel surface by thermal oxidation in air at a specific temperature, ${ }^{1}$ chemical oxidation ${ }^{2-4}$ or electrochemical oxidation. ${ }^{5-11}$ While light-colored films are obtained by

\footnotetext{
* e-mail: bocchi@dq.ufscar.br.
}

thermal oxidation, deep-colored and intense-colored films are obtained by chemical or electrochemical oxidation.

The chemical-oxidation method, firstly proposed by Hatfield and Green in 1927 and extensively studied by Evans et al., ${ }^{2-4}$ involves dipping stainless-steel samples in a hot $\left(70{ }^{\circ} \mathrm{C}\right)$ aqueous solution containing chromic and sulfuric acids $\left(2.5 \mathrm{~mol} \mathrm{~L}^{-1} \mathrm{CrO}_{3}+5.0 \mathrm{~mol} \mathrm{~L}^{-1} \mathrm{H}_{2} \mathrm{SO}_{4}\right)$ for a given time. Oxide films with several colors (e.g., blue, red, green or gold) are formed on the steel surface, depending on factors such as the nature and concentration of the solution components, immersion time, solution temperature and steel surface condition. Evans ${ }^{4}$ suggested that on steel the oxide film formation occurs by a dissolution and precipitation mechanism.

Since the redox reactions involved in the chemicaloxidation process do not occur spontaneously at room temperature, various electrochemical oxidation methods using strongly oxidizing solutions (in the presence or absence of chromic acid) were proposed for coloring stainless steel at room temperature: potential step, ${ }^{5}$ square- 
wave current pulse,,$^{6-8}$ square-wave potential pulse $e^{9,10}$ and triangular current scan methods. ${ }^{11}$ In these, the oxidizing capacity is enhanced by the application of a potential/ current signal and the oxide film is formed on steel by a mechanism similar to that for the film formation by the conventional chemical-oxidation method. The metal ions produced in the anodic dissolution of steel and in the cathodic reduction of hexavalent chromate anions are hydrolysed, leading to the precipitation of a chromiumrich oxide. ${ }^{10}$

As far as we know, the corrosion behavior of colored stainless steel was investigated only by Wang et al..$^{12,13}$ and Conrrado et al..$^{14}$ The former characterized the pitting corrosion of colored samples obtained by chemical, INCO (chemical coloring + electrolytic hardening) and electrochemical (square-wave potential pulse) processes, using anodic polarization and electrochemical impedance spectroscopy in an $\mathrm{HCl}$ solution. Their experimental results showed that the pitting resistance of the colored samples increased in the following process order: chemical < electrochemical < INCO. More recently, Conrrado et al. ${ }^{14}$ evaluated the resistance to uniform and pitting corrosion of AISI-304 stainless-steel samples colored using the alternating potential pulse method with different amplitudes ( $0.41 \mathrm{~V}, 0.42 \mathrm{~V}, 0.43 \mathrm{~V}$ and $\left.0.44 \mathrm{~V} v s . \mathrm{Hg} / \mathrm{Hg}_{2} \mathrm{SO}_{4}\right)$ and electrolysis times (10 min, $15 \mathrm{~min}, 20 \mathrm{~min}, 25 \mathrm{~min}, 30$ min, $35 \mathrm{~min}, 40 \mathrm{~min}$ and $50 \mathrm{~min}$ ). It was found that all the different colored samples were less susceptible to uniform corrosion than the non-colored ones. Furthermore, the colored samples whose oxide films were grown using the potential amplitudes of $0.42 \mathrm{~V}$ and $0.44 \mathrm{~V}$ showed lower uniform corrosion rates than those grown with other potential amplitudes. Furthermore, the susceptibility to pitting corrosion was practically the same for the colored and non-colored steel samples. As highlighted hereinbefore, the coloring methods constitute an effective way for increasing the applications and the corrosion resistance of stainless steel. Thus, in the present work a comparative study of the resistance to pitting corrosion of differently colored (using chemical ${ }^{2}$ or electrochemical ${ }^{10,11}$ methods) AISI-304 stainless-steel samples was carried out.

\section{Experimental}

A sheet (1.0-mm thick) of bright annealed austenitic AISI-304 stainless steel (ACESITA \# 2B) with the following mass composition was used in this study: $\mathrm{Cr} 17.7 \%, \mathrm{Ni}$ 7.4\%, Mn 1.2\%, Si 0.4\%, S $0.01 \%$, C $0.07 \%$ and $\mathrm{Fe}$ balanced. Specimens $10 \mathrm{~mm}$ x $75 \mathrm{~mm}$ in size were cut from the steel sheet, degreased for $10 \mathrm{~min}$ with acetone under ultrasonic stirring and then rinsed in distilled water. Before coloring, the degreased steel samples were always electroreduced $\left(i=-1.0 \mathrm{~mA} \mathrm{~cm}^{-2}\right)$ for $20 \mathrm{~min}$ in an aqueous $1.0 \mathrm{~mol} \mathrm{~L}^{-1} \mathrm{HNO}_{3}$ solution, except for steel samples colored by chemical method. The samples were colored using three different coloring methods as described hereinafter.

\section{Chemical coloring method}

The pre-treated steel samples were colored by immersion in a hot $\left(70^{\circ} \mathrm{C}\right.$ ) aqueous $5 \mathrm{~mol} \mathrm{~L}^{-1} \mathrm{H}_{2} \mathrm{SO}_{4}$ (Carlo Erba p.a.) $+2.5 \mathrm{~mol} \mathrm{~L}^{-1} \mathrm{CrO}_{3}$ (Carlo Erba, $99 \%$ ) solution, ${ }^{2}$ for different times (16 min, $19 \mathrm{~min}, 22 \mathrm{~min}, 24 \mathrm{~min}, 26 \mathrm{~min}$ and $27 \mathrm{~min}$ ). A $150 \mathrm{~mL}$ conventional cell coupled to a thermostatic bath was used for coloring the stainless-steel samples. The open-circuit potential of the samples was continuously monitored using a platinum electrode as a pseudo reference. ${ }^{13}$

\section{Electrochemical coloring methods}

A $150-\mathrm{mL}$ conventional electrochemical cell was used for coloring the stainless-steel samples. Two spiral Pt wires were used as auxiliary electrodes, and an $\mathrm{Hg} / \mathrm{Hg}_{2} \mathrm{SO}_{4}$ electrode in a $5.0 \mathrm{~mol} \mathrm{~L}^{-1} \mathrm{H}_{2} \mathrm{SO}_{4}$ solution was used as reference. The pre-treated stainless-steel samples were then immersed in the same acid solution used in the chemical coloring method $\left(5.0 \mathrm{~mol} \mathrm{~L}^{-1} \mathrm{H}_{2} \mathrm{SO}_{4}+2.5 \mathrm{~mol} \mathrm{~L}^{-1} \mathrm{CrO}_{3}\right.$ ) and immediately submitted to the potential/current program pre-established in a model 273A EG\&G PARC potentiostat/galvanostat.

The experimental parameters of the alternating potential pulse method (see Figure 1a) were chosen following results reported by Ogura $e t$ al. ${ }^{10}$ Thus, the values of $E_{1}$ and pulse width were fixed at $0.35 \mathrm{~V} v s$. $\mathrm{Hg} / \mathrm{Hg}_{2} \mathrm{SO}_{4} / 5 \mathrm{~mol} \mathrm{~L}^{-1} \mathrm{H}_{2} \mathrm{SO}_{4}$ (close to the immersion potential of stainless steel) and $10 \mathrm{~s}$, respectively. The value of $E_{2}$ was fixed at $0.76 \mathrm{~V} v s$. $\mathrm{Hg} / \mathrm{Hg}_{2} \mathrm{SO}_{4} / 5 \mathrm{~mol} \mathrm{~L}^{-1} \mathrm{H}_{2} \mathrm{SO}_{4}$ in order to have a pulse amplitude of $0.41 \mathrm{~V}$ (see Figure 1a). Electrolyses were carried out at $25^{\circ} \mathrm{C}$ for different times ( $10 \mathrm{~min}, 15 \mathrm{~min}, 20 \mathrm{~min}, 25$ $\mathrm{min}, 30 \mathrm{~min}, 35 \mathrm{~min}, 40 \mathrm{~min}$ and $50 \mathrm{~min}$ ).

The experimental parameters of the triangular current scan method (see Figure 1b) were chosen following results reported by Ogura et al. ${ }^{11}$ Thus, the current density values varied from $i_{\min }=-0.81 \mathrm{~mA} \mathrm{~cm}{ }^{-2}$ to $i_{\text {max }}=2 \mathrm{~mA} \mathrm{~cm}^{-2}$ at a scan rate of $9 \mathrm{~mA} \mathrm{~s}^{-1}$. Electrolyses were also carried out at $25^{\circ} \mathrm{C}$ for different times (10 min, $15 \mathrm{~min}, 20 \mathrm{~min}, 25 \mathrm{~min}$, $30 \mathrm{~min}, 35 \mathrm{~min}, 40 \mathrm{~min}$ and $50 \mathrm{~min}$ ). After coloring, the stainless-steel samples were removed from the solution, rinsed thoroughly with distilled water and dried in air.

The color and thickness of the oxide films grown on the stainless-steel samples were determined by measuring 


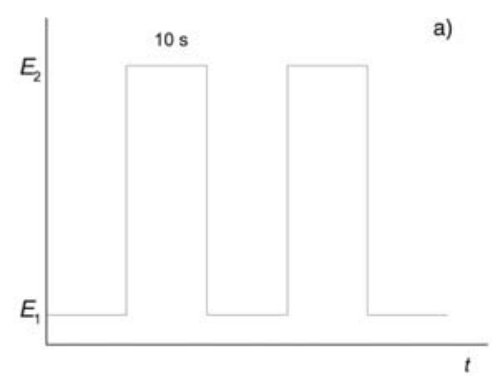

b)

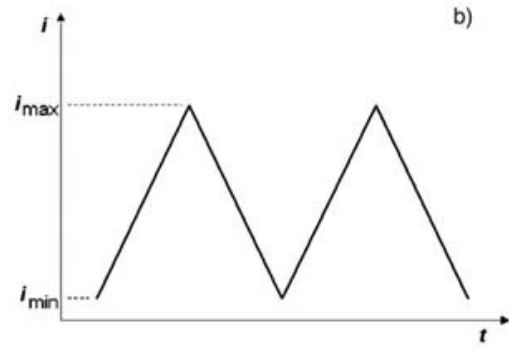

Figure 1. Diagrams illustrating the electrochemical methods used in the present study: (a) alternating potential pulses with $E_{1}=0.35 \mathrm{~V}, E_{2}$ $=0.76 \mathrm{~V}$ vs. $\mathrm{Hg} / \mathrm{Hg}_{2} \mathrm{SO}_{4} / 5 \mathrm{~mol} \mathrm{~L}^{-1} \mathrm{H}_{2} \mathrm{SO}_{4}$ and pulse width of $10 \mathrm{~s}$; (b) triangular current scan with $i_{\text {max }}=2 \mathrm{~mA} \mathrm{~cm}{ }^{-2}, i_{\min }=-0.81 \mathrm{~mA} \mathrm{~cm}^{-2}$ and scan rate of $9 \mathrm{~mA} \mathrm{~s}^{-1}$.

their spectral reflectance in the visible region $(400 \mathrm{~nm}$ $700 \mathrm{~nm}$ ). In this method, the color is defined by a point in the CIELAB color space ${ }^{15}$ that yields colorimetric coordinates representing the psychometrical correlates of the natural attributes of human color perception (hue, saturation, and lightness), expressed in terms of hue angle $\left(h_{\mathrm{ab}}\right)$, metric chroma $(C)$ and lightness $(L)$ (see Figure 2). ${ }^{16}$ The values of the metric-chroma $(a, b)$ and lightness $(L)$ coordinates were obtained through an appropriate software (ProPalette) run in a microcomputer interfaced to the spectrophotometer (Spectra Flash-Data Color - 500).

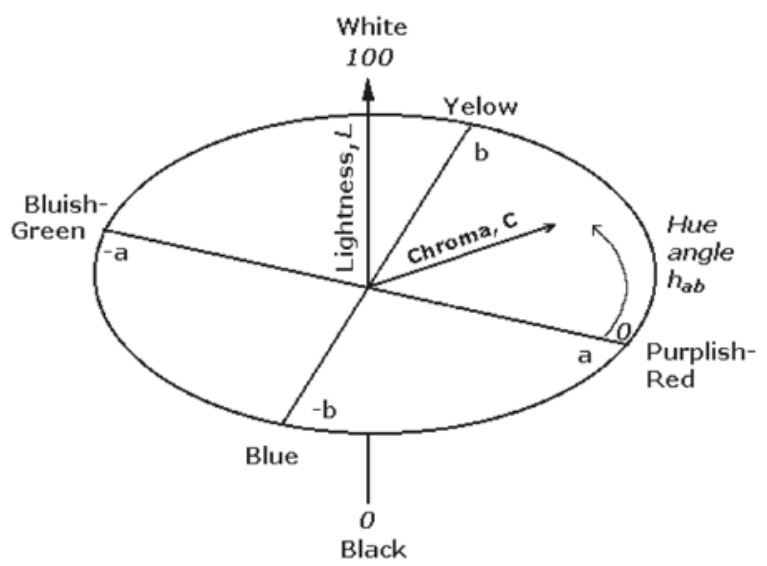

Figure 2. Diagram illustrating the color parameters: hue angle, $h_{\mathrm{ab}}$ (blue, purplish-red, yellow, bluish-green); lightness, $L$ (white I black) and metric chroma, $C$ (dull I vivid).
Susceptibility of the colored steel samples to pitting corrosion was evaluated by potentiodynamic polarization curves and immersion tests. The former were obtained at $25{ }^{\circ} \mathrm{C}$ in a deaerated aqueous $0.62 \mathrm{~mol} \mathrm{~L}^{-1} \mathrm{NaCl}$ (Merck p.a.) solution. ${ }^{17} \mathrm{~A}$ conventional three-electrode electrochemical cell was used. The counter electrode was a spiral Pt wire and a saturated calomel electrode (SCE) was used as reference for the potential measurements. An Autolab PGSTAT30 potentiostat/galvanostat from Eco Chemie, controlled by the GPES software, was used to obtain the polarization curves. The colored steel samples (with 200-250 nm oxide films) were immersed $1 \mathrm{~cm}$ in the $\mathrm{NaCl}$ solution and immediately polarized at a potential about $50 \mathrm{mV}$ more negative than the corrosion potential. After approximately one minute, the potentiodynamic polarization curves were initiated in the anodic direction at a scanning rate of $0.2 \mathrm{mV} \mathrm{s}^{-1}$. When the current reached $5 \mathrm{~mA}$, the scanning direction was reversed toward more negative potentials until the hysteresis loop was closed or the corrosion potential was reached. Four polarization curves were always obtained for each one of the steel samples electrolyzed in a given experimental condition.

The immersion tests were carried out in an aqueous 0.4 mol L ${ }^{-1} \mathrm{HCl}$ (Mallinckrodt p.a.) solution using an electrochemical cell specially made in acrylic. The colored steel samples (with 200-250 nm oxide films) were adapted in a circular opening $(2 \mathrm{~cm}$ diameter $)$ in the cell bottom. Periodically, an electrochemical impedance spectrum was obtained at the open circuit potential using an Autolab FRA2 module, coupled to the PGSTAT30 potentiostat/ galvanostat, applying a $5 \mathrm{mV}$ (rms) ac signal and scanning the $100 \mathrm{kHz}-10 \mathrm{mHz}$ frequency range. The counter electrode was a circular platinum grid (2-cm diameter) and a saturated calomel electrode (SCE) was used as reference for the potential measurements.

\section{Results and Discussion}

The several visual colors obtained for the AISI-304 stainless-steel samples colored by the electrochemical or chemical methods using different electrolysis or immersion times are listed in Tables 1 and 2, respectively. Clearly, the obtained colors depend on the immersion time and coloring method used. While the colors of the electrochemically colored samples were predominantly gold, red and blue, those of the chemically colored samples were much less varied, being mostly brown.

Typical reflectance spectra are presented in Figure 3 for stainless-steel samples colored using the triangular current scan method using different electrolysis times. From spectra such as these, the values of the psychometric- 
Table 1. Visual colors of the oxide films grown on stainless-steel samples using the alternating potential pulse and triangular current scan methods for different electrolysis times

\begin{tabular}{lcc}
\hline & \multicolumn{2}{c}{ Visual colors } \\
\cline { 2 - 3 } t/min & $\begin{array}{c}\text { Alternating potential pulse } \\
\text { method }\left(E_{2}-E_{1}=0.41 \mathrm{~V}\right)\end{array}$ & $\begin{array}{c}\text { Triangular current scan } \\
\text { method }\end{array}$ \\
\hline 10 & gold & brown \\
15 & brown & reddish blue \\
20 & brown & blue \\
25 & blue & greenish blue \\
30 & greenish blue & greenish gold \\
35 & green & gold \\
40 & golden green & brown \\
50 & brown & reddish brown \\
\hline
\end{tabular}

Table 2. Visual colors of the oxide films grown on stainless-steel samples using the chemical method for different immersion times

\begin{tabular}{cc}
\hline $\mathrm{t} / \mathrm{min}$ & Visual color \\
\hline 16 & blue \\
19 & brown \\
22 & reddish-blue \\
24 & brown \\
26 & brown \\
27 & greenish-brown \\
\hline
\end{tabular}

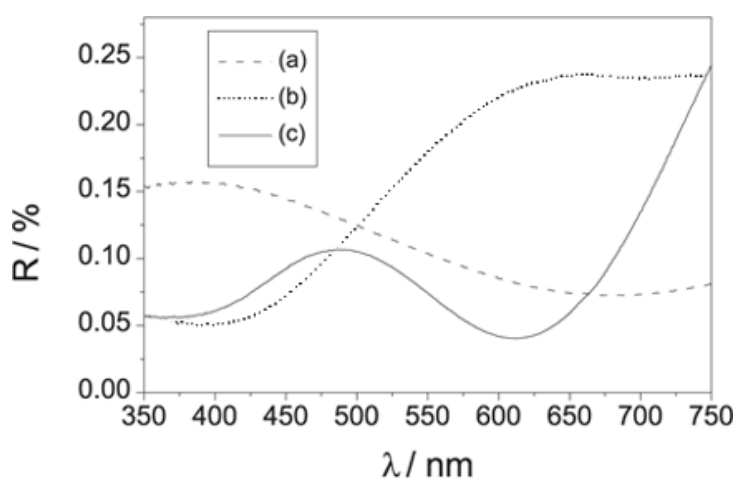

Figure 3. Reflectance spectra of stainless-steel samples colored using the triangular current scan method for different electrolysis times: (a) $15 \mathrm{~min}$, (b) $30 \mathrm{~min}$, and (c) $50 \mathrm{~min}$.

chroma $(a, b)$ and brightness $(L)$ coordinates for the colored steel samples can be calculated. These coordinates are shown in Figures 4, 5 and 6 for all the colored steel samples produced in this work (previously presented in Tables 1 and 2); each point in these figures represents the color obtained for a given electrolysis or immersion time. In a general way, as the time increases the oxide films thicken and thus display different colors, causing the chromatic coordinates to move clockwise; for longer times, the colors become repetitive (secondary colors).

In each spectrum such as those shown in Figure 3 there is at least one reflectance maximum or one reflectance

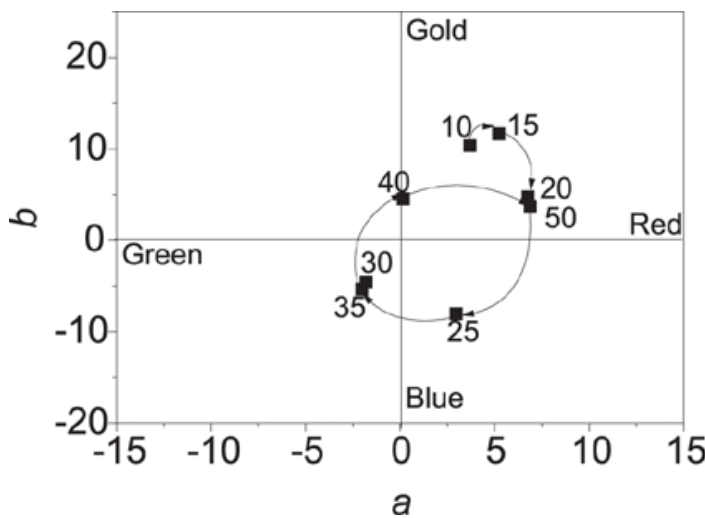

Figure 4. Chromatic coordinates of oxide films grown on AISI-304 stainless steel using the alternating potential pulse method for different electrolysis times (indicated alongside the points, in min).

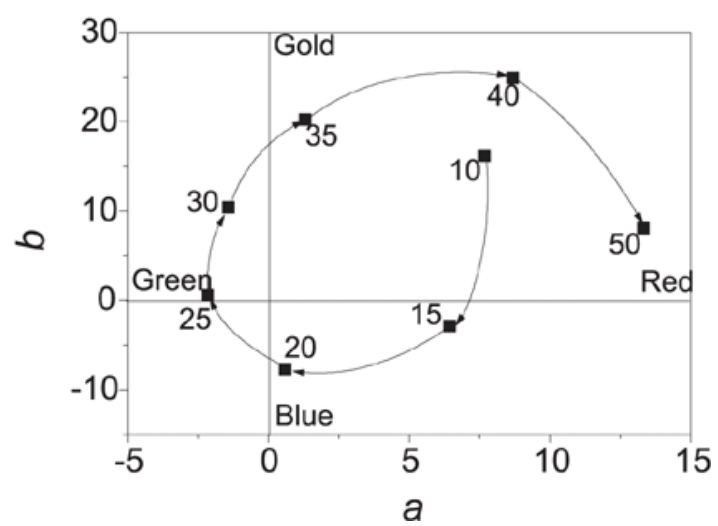

Figure 5. Chromatic coordinates of oxide films grown on AISI-304 stainless steel using the triangular current scan method for different electrolysis times (indicated alongside the points, in min).

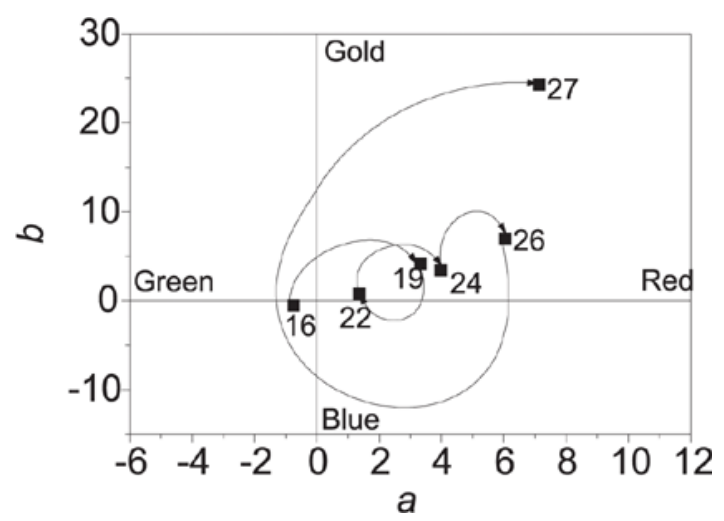

Figure 6. Chromatic coordinates of oxide films grown on AISI-304 stainless steel using the chemical method for different immersion times (indicated alongside the points, in $\min$ ).

minimum in the visible region. For a normal viewing of the film, the reflectance reaches either a maximum or a minimum when equation 1 or 2 holds, respectively, from which the thickness of the oxide film can be estimated: ${ }^{10}$ 
$2 n d=m \lambda_{\max }$

$2 n d=(m+1) \lambda_{\text {min }}$

In these equations, $n$ is the refractive index of the oxide film (assumed to be 2.2), ${ }^{4} d$ the film thickness, $m$ the interference order (an integer), and $\lambda_{\max }$ and $\lambda_{\min }$ the wavelengths at the reflectance maximum and minimum, respectively. For spectra that present both reflectance maximum and minimum in the visible region, the corresponding film thickness is obtained from the previous equations and given by:

$$
d=\frac{\lambda_{\text {min }}}{4 n\left(1-\frac{\lambda_{\min }}{\lambda_{\text {max }}}\right)}
$$

As values of $\lambda_{\max }$ and $\lambda_{\min }$, neighboring reflectance maximum and minimum were selected, choosing the latter at the shortest wavelength possible. ${ }^{10}$ The thinnest oxide film capable of being evaluated by this technique is approximately $30 \mathrm{~nm}$ thick. ${ }^{18}$

Regardless of the coloring method used, the thickness of the films increases linearly with the electrolysis or immersion time, as shown in Figure 7. The thickness values and also the trends observed in Figure 7 agree well with those reported by Evans et al. ${ }^{2}$ and Ogura et al. ${ }^{10}$ for oxide films grown by chemical and electrochemical methods, respectively. While the oxide films grown by the alternating potential pulse and chemical methods have thickness values in the range $70-400 \mathrm{~nm}$, the oxide films grown by the triangular current scan method have thickness values in a narrower range, 70-250 $\mathrm{nm}$. It is important to emphasize that the oxide films grown by the chemical method thickened at a faster rate than those grown by the electrochemical methods.

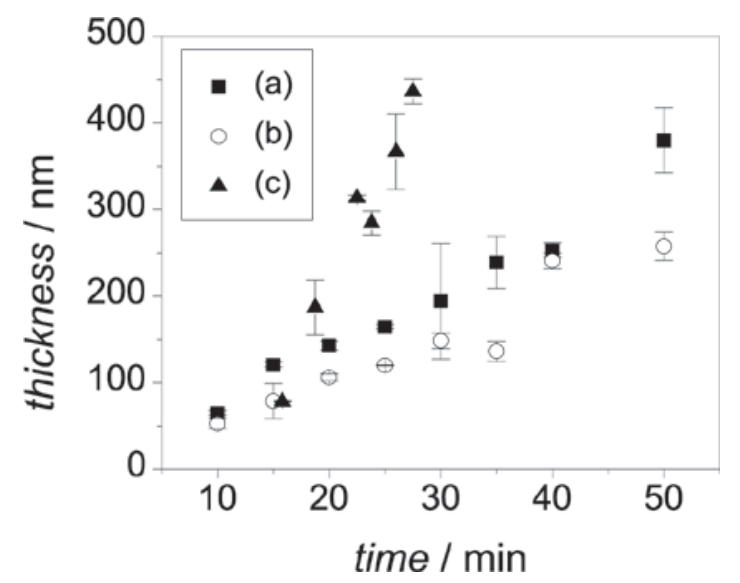

Figure 7. Thickness as a function of electrolysis/immersion time for oxide films grown on AISI-304 stainless steel using the (a) alternating potential pulse, (b) triangular current scan, and (c) chemical methods.
Figure 8 shows typical potentiodynamic polarization curves obtained in deaerated $0.62 \mathrm{~mol} \mathrm{~L}^{-1} \mathrm{NaCl}$ for stainless-steel samples previously colored using chemical and electrochemical methods; for comparison, a curve for a non-colored (as received) stainless-steel sample is also shown. The visual color of all steel samples was practically unchanged after the polarization curves were obtained. The current density values obtained for the colored and non-colored samples are almost of the same order of magnitude, except that for the polarization curve obtained for the sample colored by the chemical method. In this case the value of the current density is greater by approximately one order of magnitude, indicating that the electrochemical reactions kinetics is faster, probably due to the fact that the colored oxide film grown in such conditions has a higher pore density. Considering that the potential ranges in the cathodic branches of these curves are quite narrow, their analysis becomes difficult. The active-passive region in the anodic branches of all polarization curves is absent, as also previously reported by Wang et al., ${ }^{13}$ indicating the presence of a passivating film on the steel samples. The values for the corrosion potential $\left(E_{\text {cor }}\right)$, critical pitting potential $\left(E_{\text {pit }}\right)$ and protection or repassivation potential $\left(E_{\text {prot }}\right)$ differ significantly for the different stainless-steel samples, colored or not. The polarization curves obtained for the non-colored and chemically colored samples presented $E_{\text {cor }}$ values more negative than those for the electrochemically colored samples, a fact that will be discussed below. In spite of this, $E_{\text {pit }}$ and $E_{\text {prot }}$ values are very close for all the colored samples (chemically and electrochemically colored).

A material's susceptibility to pitting corrosion can be evaluated by the hysteresis area observed in its polarization curve obtained in an aqueous solution containing chloride

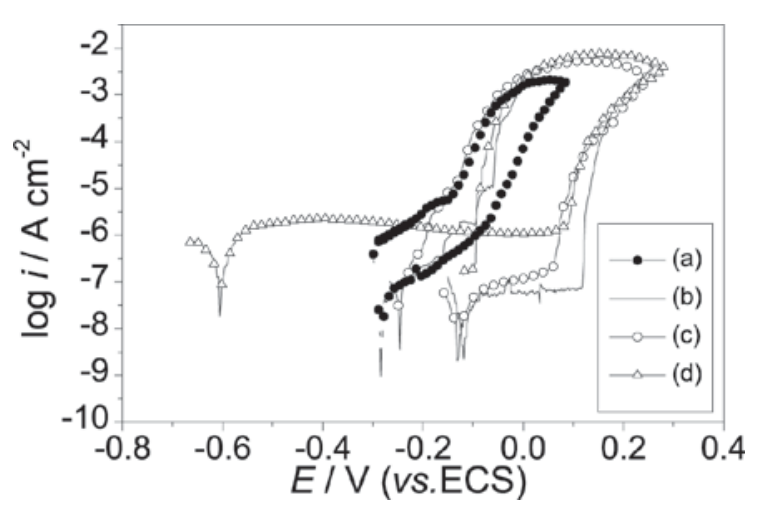

Figure 8. Typical potentiodynamic polarization curves $(v=0.2 \mathrm{mV}$ $\mathrm{s}^{-1}$ ) obtained at $25^{\circ} \mathrm{C}$ in dearated $0.62 \mathrm{~mol} \mathrm{~L}^{-1} \mathrm{NaCl}$ for AISI-304 stainless-steel (a) non-colored samples (as received) and previously colored samples (200-250-nm oxide films) using the (b) alternating potential pulse, (c) triangular current scan and (d) chemical methods. 
ions. This area can be considered as being proportional to the difference between the critical pitting potential and the protection potential $\left(E_{\text {pit }}-E_{\text {prot }}\right) ;{ }^{19}$ the smaller this potential difference, the better the material's pitting corrosion resistance. Independently of the oxide films thickness, the $\left(E_{\text {pit }}-E_{\text {prot }}\right)$ values were found to be $0.20 \pm$ $0.05 \mathrm{~V}$ and $0.35 \pm 0.05 \mathrm{~V}$ for chemically and electrochemically colored samples, respectively. As can be seen in Figure 8, the protection or repassivation potential $\left(E_{\text {prot }}\right)$ was not observed for non-colored steel in the potential range studied and, therefore, the $\left(E_{\text {pit }}-E_{\text {prot }}\right)$ value was not calculated for this sample. In spite of this, the $\left(E_{\mathrm{pit}}\right.$ $-E_{\text {prot }}$ ) value for non-colored steel should be greater than those obtained for the colored samples. These results indicate that the colored oxide films have a protective effect against pitting corrosion.

The difference between the critical pitting potential and the corrosion potential $\left(E_{\text {pit }}-E_{\text {cor }}\right)$ can also be used to evaluate a material's susceptibility to pitting corrosion. Figure 9 shows the $\left(E_{\text {pit }}-E_{\text {cor }}\right)$ values as a function of the thickness of the oxide films grown on AISI-304 stainless steel by the three coloring methods. It is important to emphasize that these $\left(E_{\text {pit }}-E_{\text {cor }}\right)$ values are averages from polarization curves for at least four different steel samples (colored or not); the respective standard deviations for the $\left(E_{\text {pit }}-E_{\text {cor }}\right)$ values were not shown in this figure to avoid cluttering it. The $\left(E_{\text {pit }}-E_{\text {cor }}\right)$ values are in the range 0.1-0.3 $\mathrm{V}$ and $0.6-0.9 \mathrm{~V}$ for the electrochemically and chemically colored samples, respectively. Most of the values of this potential difference for the colored samples are greater (ca. $0.15 \mathrm{~V}$ ) than those for the non-colored samples, indicating also that the colored oxide films have a protective effect against pitting corrosion. Among the colored samples, the $\left(E_{\text {pit }}-E_{\text {cor }}\right)$ values for the chemically colored samples are greater than those for the electrochemically colored samples. So, the chemically

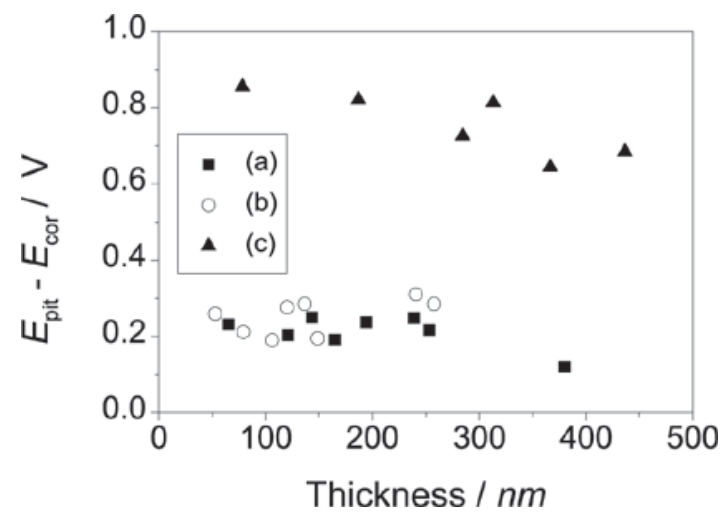

Figure 9. $\left(E_{\text {pit }}-E_{\text {cor }}\right)$ as a function of the thickness of the oxide films grown on AISI-304 stainless-steel samples using the (a) alternating potential pulse, (b) triangular current scan and (c) chemical methods. colored samples exhibit a wider potential range free of pitting corrosion when they are in service.

Immersion tests were also employed to evaluate the pitting corrosion resistance of non-colored (as received) stainless-steel samples and of samples previously colored by chemical and electrochemical methods; this evaluation was carried out by electrochemical impedance spectroscopy (EIS). At first, an aerated aqueous $0.62 \mathrm{~mol}$ $\mathrm{L}^{-1} \mathrm{NaCl}$ solution was used in these tests; however, the impedance spectra of the samples remained practically unchanged after 5 days even for the non-colored sample. Due to this, aerated aqueous $\mathrm{HCl}$ solutions $\left(0.3 \mathrm{~mol} \mathrm{~L}^{-1}\right.$, $0.4 \mathrm{~mol} \mathrm{~L}^{-1}, 0.5 \mathrm{~mol} \mathrm{~L}^{-1}$ and $0.6 \mathrm{~mol} \mathrm{~L}^{-1}$ ) were used in immersion tests for a few samples. As the impedance spectra obtained for samples immersed in $0.4 \mathrm{~mol} \mathrm{~L}^{-1} \mathrm{HCl}$ showed significant changes in the time range $5 \mathrm{~h}$ to $20 \mathrm{~h}$, only this acid solution was chosen for the immersion tests of all the stainless-steel samples investigated. The impedance spectra (complex-plane or Nyquist plots) obtained after different immersion times in aerated $0.4 \mathrm{~mol} \mathrm{~L}^{-1} \mathrm{HCl}$ solution at the open circuit potential or corrosion potential are illustrated in Figure 10. The impedance profiles of the different steel samples were found to depend on the immersion time; the polarization resistance associated to these spectra, defined as $R_{\mathrm{p}}=\lim _{\text {wo o }}$ [Z(jw)], becomes smaller as the immersion time increases. In the case of the non-colored samples, an inductive contribution is clearly present after all the different immersion times; for the colored samples, such a contribution becomes apparent only after the longest immersion times. These characteristics of the impedance profiles were also observed by Wang et al. ${ }^{13}$ for colored films on stainless steel formed by chemical, INCO (chemical coloring + electrolytic hardening) and electrochemical (square-wave potential pulse) processes in an aerated aqueous $1.0 \mathrm{~mol} \mathrm{~L}^{-1} \mathrm{HCl}$ solution. These authors demonstrated by scanning-electron-microscopy analysis that such variations in the impedance profiles could be correlated to the occurrence of pitting corrosion.

In order to determine approximate values for $R_{\mathrm{p}}$ associated to the impedance spectra shown in Figure 10, a quite simplified procedure was adopted, available within the software that manages the Autolab FRA2 module: the fitting to the data of a Randles type equivalent circuit $\left[R_{\mathrm{s}}\left(Q R_{\mathrm{p}}\right)\right.$, where $R_{\mathrm{s}}$ is the electrolyte resistance, $Q$ a constant phase element (CPE) and $R_{\mathrm{p}}$ the polarization resistance]. The approximate $R_{\mathrm{p}}$ values thus obtained at different immersion times are shown in the boxes within Figures 10ad. In a general way, the colored samples presented $R_{\mathrm{p}}$ values decreasing from the range $5-16 \mathrm{k}: \mathrm{cm}^{2}$ in the first hour to the range $0.5-3 \mathrm{k}: \mathrm{cm}^{2}$ after almost $10 \mathrm{~h}$ of immersion. These results also indicate that the colored oxide films have 

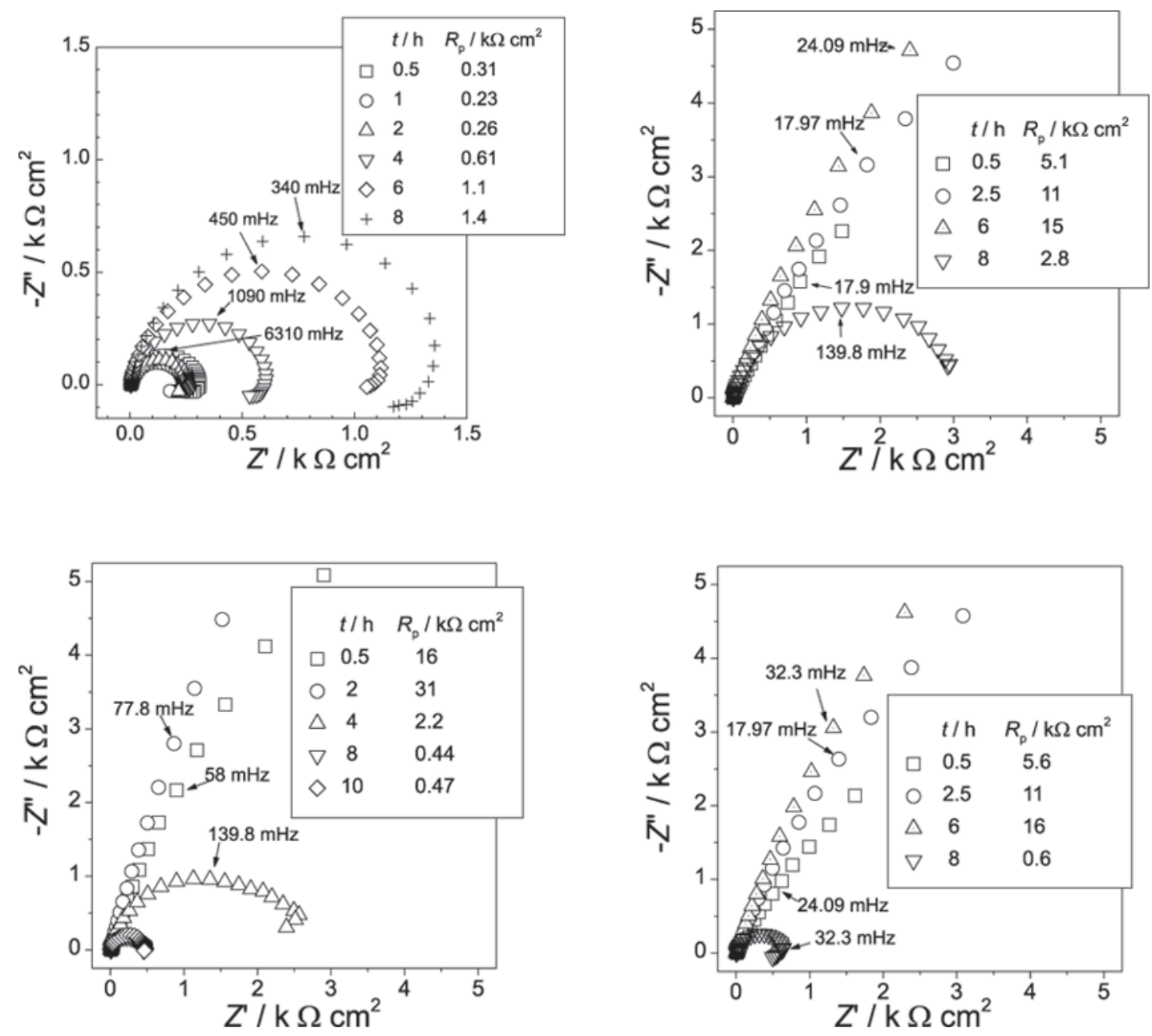

Figure 10. Complex-plane plots obtained at the open-circuit potential $\left(E_{\text {cor }}\right)$ after different immersion times in aerated $0.4 \mathrm{~mol} \mathrm{~L}^{-1} \mathrm{HCl}$ for AISI304 stainless-steel (a) non-colored samples and previously colored samples (with 200-250-nm oxide films) using the (b) alternating potential pulse, (c) triangular current scan and (d) chemical methods. The boxes within the figures show the approximate values of $R_{\mathrm{p}}$ determined by fitting the respective impedance spectra using a Randles-type equivalent circuit (see text).

a protective effect against pitting corrosion at least in the first hours of immersion; however, among the steel samples colored by different methods, there is no significant difference in this protective effect. On the other hand, the $R_{\mathrm{p}}$ values for the non-colored steel sample were $c a .0 .23: \mathrm{cm}^{2}$ and ca. $1.4: \mathrm{cm}^{2}$ after immersion for $1 \mathrm{~h}$ and $8 \mathrm{~h}$, respectively. This increase in the $R_{\mathrm{p}}$ for the non-colored steel sample, which occurred despite that pitting corrosion was already observed in the beginning of this test, may be associated with the thickening of the passivating films during the immersion test. Since the equivalent circuit used to determine the $R_{\mathrm{p}}$ values is only a rough approximation of the one necessary to fit the data, the values associated to the $\mathrm{CPE}$ are not being presented; a more refined analysis of the impedance data obtained (comprising a larger data set) is being carried out.

Figure 11 shows the $E_{\text {cor }}$ values recorded after the samples were immersed for different times in the aerated

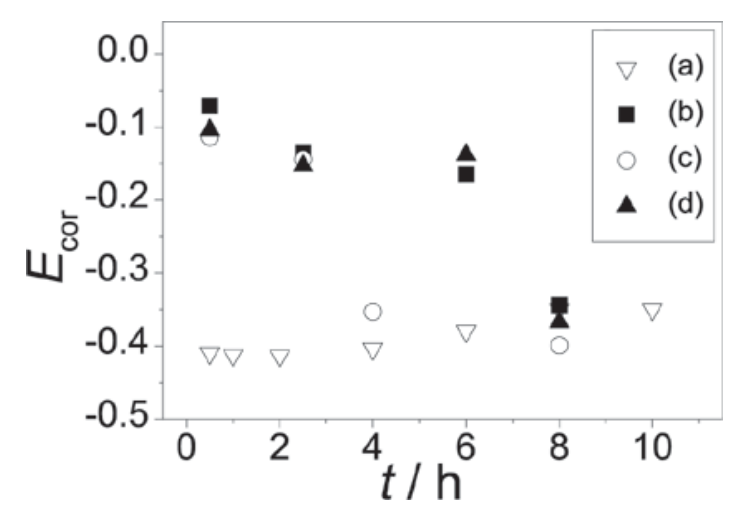

Figure 11. $E_{\text {cor }}$ values as a function of the immersion time, for immersion tests in aerated $0.4 \mathrm{~mol} \mathrm{~L}^{-1} \mathrm{HCl}$ for AISI-304 stainlesssteel (a) non-colored samples and previously colored samples (with 200-250-nm oxide films) using the (b) alternating potential pulse, (c) triangular current scan and (d) chemical methods.

$0.4 \mathrm{~mol} \mathrm{~L}^{-1} \mathrm{HCl}$ solution. While for the colored samples $E_{\text {cor }}$ decreased in the first hours of immersion, it increased 
for the non-colored sample. Furthermore, after 6-8 h of immersion, $E_{\text {cor }}$ is practically the same for all the steel samples (colored and non-colored), a result that agrees well with those obtained by EIS.

The knowledge of the nature, morphology and properties of thick oxide films formed on AISI-304 stainless steel is useful for the comprehension of the above results concerning the evaluation of the pitting corrosion resistance of the stainless-steel samples previously colored by chemical and electrochemical methods. Recently, the growth and properties of Cr-rich thick oxide films on type 304 stainless steel grown by square-wave potential pulse polarization in $5 \mathrm{~mol} \mathrm{~L}^{-1} \mathrm{H}_{2} \mathrm{SO}_{4}$ at $50-80{ }^{\circ} \mathrm{C}$ were investigated by Fujimoto et al. ${ }^{20-22}$ Results obtained by transmission electron microscopy showed that the films were extraordinarily thick and porous, consisting of nanocrystalline grains of diameters in the range $20-30 \mathrm{~nm}$. Based on XPS, TEM-EDX, EIS and photoelectrochemical data, these authors showed that the oxide films formed by a cathodic process (when the lower and higher potentials of the square wave are in the passive and transpassive regions of $\mathrm{Cr}$, as in the present work) are composed of an inner thin passive film (complex iron and chromium oxide) and an outer thick and porous film that seems to consist of nanocrystalline- $\mathrm{Cr}_{2} \mathrm{FeO}_{4}$-spinel oxide particles covered with an electronic insulating film of disordered chromium oxide or hydroxide. So, the formation of an oxide film with outer layers of different structure or stoichiometry may possibly explain the different values of $E_{\text {cor }}$ obtained for the colored steel samples investigated in this work. On the other hand, the fact that the values of $E_{\text {pit }}$ obtained for all colored steel samples are similar, as shown in Figure 8, may possibly be explained by considering that the inner layer of the oxide films is the same independently of the coloring method used. Moreover, the outer layer of the oxide films may also explain why the colored films present a protective effect against pitting corrosion in the accelerated test in dearated $0.62 \mathrm{~mol} \mathrm{~L}^{-1} \mathrm{NaCl}$ (Figure 8) and in the first hours of the extended immersion tests in aerated $0.4 \mathrm{~mol} \mathrm{~L}^{-1} \mathrm{HCl}$ (Figure 10). For longer exposition times $(8-10 \mathrm{~h})$ the non-colored and colored steel samples present the same behavior probably because the inner layer of the colored films is similar to the passivating film formed on non-colored steel samples.

\section{Conclusions}

The present study demonstrated that the different coloring methods for stainless steels proposed in the literature are effectively applicable to commercial AISI304 stainless steels. The oxide films grown chemically and electrochemically on Acesita's AISI-304 \# 2B stainless steel presented good adherence and several colors. Moreover, the spectral reflectance technique proved to be useful to clearly define the colors of the oxide films and also to estimate their thickness. The oxide films grown by the alternating potential pulse and chemical methods presented thickness values in the range 70-400 nm, while these values were in the range $70-250 \mathrm{~nm}$ for oxide films grown by the triangular current scan method.

Polarization curves obtained in deaerated $0.62 \mathrm{~mol} \mathrm{~L}^{-1}$ $\mathrm{NaCl}$ for colored and non-colored (as received) samples showed that the colored oxide films have a protective effect against pitting corrosion, regardless of the coloring method used. The $\left(E_{\text {pit }}-E_{\text {cor }}\right)$ values for most colored samples were greater than those for the non-colored ones. EIS data associated to immersion tests carried out in $0.4 \mathrm{~mol} \mathrm{~L}^{-1}$ $\mathrm{HCl}$ also showed that the colored films had a protective effect against pitting corrosion in the first hours of exposition. However, for longer exposition times (8-10 h) the colored and non-colored steel samples presented the same behavior, i. e., very similar values of polarization resistance, $R_{\mathrm{p}}$, and corrosion potential, $E_{\text {cor }}$.

\section{Acknowledgements}

The financial support of this work by the Brazilian research funding agencies FAPESP, CNPq and CAPES is gratefully acknowledged.

\section{References}

1. Sygeoda, S. A.; Belg. Pat. 869885, February 1979.

2. Evans, T. E.; Hart, A. C.; James, H.; Smith, V. A.; Trans. Inst. Met. Finish. 1972, 50, 77.

3. Evans, T. E.; Hart, A. C.; Skedgell, A. E.; Trans. Inst. Met. Finish. 1973, 51, 108.

4. Evans, T. E.; Corros. Sci. 1977, 17, 105.

5. Ogura, K.; Tsujigo, M.; Sakurai, K.; Yano, J.; J. Electrochem. Soc. 1993, 140, 1311.

6. Lin, C. J.; Duh, J. G.; Surf. Coat. Technol. 1994, 70, 79.

7. Lin, C. J.; Duh, J. G.; Surf. Coat. Technol. 1995, 73, 52.

8. Lin, C. J.; Duh, J. G.; Surf. Coat. Technol. 1996, 85, 175.

9. Fujimoto, S.; Shibata, T.; Wada, K.; Tsutae, T.; Corros. Sci. 1993, 35, 147.

10. Ogura, K.; Sakurai, K.; Uehara, S.; J. Electrochem. Soc. 1994, $141,648$.

11. Ogura, K.; Lou, W.; Nakayama, M.; Electrochim. Acta 1996, $41,2849$.

12. Wang, J. H.; Duh, J. G.; Shih, H. C.; J. Mat. Sci. Lett. 1995, 14, 53.

13. Wang, J. H.; Duh, J. G.; Shih, H. C.; Surf. Coat. Technol. 1996, $78,248$. 
14. Conrrado, R.; Bocchi, N.; Rocha-Filho, R. C.; Biaggio, S. R.; Electrochim. Acta 2003, 48, 2417.

15. Colorimetry. Recomendations on Uniform Colour Spaces, Colours Differences Equations. Psychometric Terms; Publication no. 15-2, $2^{\text {nd }}$ ed., Central Bureau of the CIE: Vienna, 1986.

16. Gonnet, J. F.; Food Chemistry 1998, 63, 409.

17. ASTM; Standard Test Method for Conducting Cyclic Potentyodinamic Polarization Measurements for Localized Corrosion Susceptibility of Iron-, Nickel-, Cobalt-Based Alloys, G-61, 1986.

18. Fujimoto, S.; Nakatsu, H.; Hata, S.; Shibata, T.; Corros. Sci. 1996, $38,1473$.
19. Trethewey, K. R.; Chamberlain, J; Corrosion for Science and Engineering, $2^{\text {nd }}$ ed., Longman: Singapore, 1995.

20. Fujimoto, S.; Shibata, T.; Mat. Sci. Forum 1995, 185, 741.

21. Fujimoto, S.; Kawachi, S.; Nishio, T.; Shibata, T.; J. Electroanal. Chem. 1999, 473, 265.

22. Fujimoto, S.; Tsujino, K.; Shibata, T.; Electrochim. Acta 2001, 47, 543.

Received: October 14, 2003

Published on the web: May 17, 2004

FAPESP helped in meeting the publication costs of this article. 